\title{
Morphometric Analysis of Patapur Micro-watershed in North-Eastern Dry Zone of Karnataka Using Geographical Information System: A Case Study
}

\author{
B.D. Premanand ${ }^{1 *}$, U. Satishkumar ${ }^{1}$, B. Maheshwara Babu ${ }^{1}$, S.K. Parasappa ${ }^{2}$, \\ Mallikarjuna M. Dandu ${ }^{3}$, Ibrahim Kaleel ${ }^{4}$, N.L. Rajesh ${ }^{5}$ and S.A. Biradar ${ }^{6}$ \\ ${ }^{1}$ Department of Soil and Water Conservation Engineering, College of Agricultural \\ Engineering, UAS, Raichur, Karnataka, India \\ ${ }^{2}$ Department of Agricultural Engineering, College of Agriculture, \\ UAS, Dharwad, Karnataka, India \\ ${ }^{3}$ Department of Agricultural Engineering, College of Agriculture, B' Gudi, \\ UAS, Raichur, Karnataka, India \\ ${ }^{4}$ PFDC-WTC, PJTSAU, Rajendranagar, Hyderbad, India \\ ${ }^{5}$ Department of Soil Science and Agricultural Chemistry, College of Agriculture, \\ UAS, Raichur, Karnataka, India \\ ${ }^{6}$ KVK, Vijayapaur, UAS, Dharwad, Karnataka, India \\ *Corresponding author
}

\section{A B S T R A C T}

The application of remote sensing and geographical information system for the analysis of morphometric parameters are found to be of immense utility in watershed prioritization for soil, water conservation and natural resources management at micro level. Geomorphological analysis is the systematic description of watershed geometry and its stream system. These parameters directly or indirectly reflect the response of entire

\section{Keywords}

Morphometry, Micro-watershed, QGIS techniques, DEM

Article Info

Accepted:

07 March 2018

Available Online:

10 April 2018 watershed based on causative factors that are affecting runoff and sediment loss. To prepare a watershed development plan, morphometric analysis have been studied in the Patapur micro-watershed (488.75 ha), being located at Raichur district of Karnataka. The boundary of the watershed was digitized from the SOI (Survey of India) toposheet and also DEM and slope maps were prepared with the help GIS techniques (QGIS). The morphometric parameters such as linear, aerial and relief aspects have been determined to understand the watershed characteristics. In the Patapur micro-watershed the bifurcation ratio $\left(R_{b}\right)$ was varied from 1.75 to 4.0 with average of 2.88 which indicates that on undistorted geologic structure and drainage system of moderate peaks and lower order streams. The values of form factor $\left(R_{f}\right)$, shape factor $\left(S_{b}\right)$, circulatory ratio $\left(R_{c}\right)$ and elongation ratios $\left(\mathrm{R}_{\mathrm{e}}\right)$ were $0.329,2.28,0.512$ and0.647 respectively which indicates moderately elongated micro-watershed with leading moderate influence on time parameters. The estimated values of relief, relief ratio $(\mathrm{Rr})$ and relative relief $(\mathrm{RR})$ were found to be $114 \mathrm{~m}, 0.130$ and 0.05 respectively, these indicates the possibly moderate erosion. Over all study suggests that the watershed should be treated with soil and water conservation measures. 


\section{Introduction}

Morphometry is the measurement and mathematical analysis of the configuration of the earth's surface, including shape and dimension of its landforms, physical properties, interrelationship of morphological characteristics and hydrological behavior. The morphometric characteristics at given watershed scale contains important information regarding its formation and development due to all hydrologic and geomorphic processes occur within the watershed and it provides a quantitative description of the drainage system, which is an important aspect of the characteristics of watersheds. The morphological characteristics of a basin represent its attributes, which may be employed in synthesizing its hydrological response.

Hydrologists and geomorphologists have recognized that certain relations are most important between runoff characteristics, and geographic and geomorphic characteristics of drainage basin systems. QGIS and remote sensing techniques have opened up wide range of avenues for effective watershed management, as they provide a flexible environment and a powerful tool for the manipulation and analysis of spatial information. The outcome of analysis of linear and areal parameters would be important in determining the effect of catchment characteristics and distribution of stream network of different orders within the catchment area.

\section{Materials and Methods}

The present study was carried out in the Patapur micro watershed (WS-Code: 4D3A4B1e) named after two villages (Patapur and Goladinni) found near the watershed, covers a total geographical area of 488.75 ha, which is part of the Tungabhadra sub basin and falls within the North-Eastern dry zone (Zone-2 of Region-1) of Karnataka and lies between $16^{\circ} 07^{\prime} 35.9^{\prime \prime} \mathrm{N}$ latitude and $76^{\circ} 51^{\prime}$ $33.3^{\prime \prime}$ E longitudes to $16^{\circ} 08^{\prime} 22.3^{\prime \prime} \mathrm{N}$ latitude and $76^{\circ} 53^{\prime} 27.7^{\prime \prime} \mathrm{E}$ longitudes with an average elevation of $460 \mathrm{~m}$ above mean sea level (MSL) altitude in the Raichur district, Karnataka, India.

This is located at about $65 \mathrm{~km}$ from the Raichur city on Raichur-Lingasugur state high way (SH No. 20) Figure 1. The hydrological delineated Patapur micro watershed considered for this study covered under the Survey of India toposheet of 56 D/16 $(1: 50,000)$. The elevation of the micro watershed ranges from $432 \mathrm{~m}$ to $546 \mathrm{~m}$ above mean sea level (MSL). The minimum elevation of $432 \mathrm{~m}$ found near the outlet where gauging station is existing and the maximum elevation 546 meters is over the hillocks at upstream side of the watershed.

The geo-morphological characteristics of the micro-watershed were determined by digitizing the SoI toposheet using open source Quantum GIS (QGIS, version 2.6.1 Brighton) software and subsequent, cleaning editing and assigning topology produced a database in terms of linear, aerial and relief aspects of the watershed.

The Patapur micro-watershed boundary was delineated using geospatial tools viz. QGIS and QSWAT. The morphological parameters directly or indirectly reflect the entire watershed behaviour on causative factors affecting runoff and sediment loss. The parameters namely size, shape, slope, relief, stream density and stream network system were worked out from the drainage map derived from DEM using the capabilities of open source QGIS software and Google earth images. The drainage map of the study area was used for quantitative analysis of the drainage basin. 


\section{Linear aspects of channel systems}

The linear aspects of morphometric analysis of basin include stream order, stream length, mean stream length, stream length ratio and bifurcation ratio. There are different systems of ordering streams that are available. Strahler's system, which is a slightly modified of Hortons system, has been followed because of its simplicity, where the smallest, unbranched fingertip streams are designated as $1^{\text {st }}$ order, the confluence of two $1^{\text {st }}$ order channels give a channels segments of $2^{\text {nd }}$ order, two $2^{\text {nd }}$ order streams join to form a segment of $3^{\text {rd }}$ order and so on. When two channel of different order join then the higher order is maintained. The trunk stream is the stream segment of highest order. It is found that Patapur micro-watershed tributaries are of $3^{\text {rd }}$ order. In all 12 streams were identified of which 7 are first order, 4 are second order, and 1 is $3^{\text {rd }}$ order. Drainage patterns of stream network from the micro-watershed have been observed as mainly of dendritic type which indicates the homogeneity in texture and lack of structural control. The properties of the stream networks are very important to study basin characteristics (Strahler, 2002).

\section{Basin length $\left(\mathbf{L}_{\mathbf{b}}\right)$}

It is the maximum length of the basin measured from the outlet to the remotest point. It was measured using the following equation;

$$
\mathrm{L}_{\mathrm{b}}=1.312 \times \mathrm{A}^{0.568}(1)
$$

Where,

$\mathrm{L}_{\mathrm{b}}=$ Basin length, $\mathrm{km}$

$\mathrm{A}=$ Area of the basin, $\mathrm{km}^{2}$

\section{Average basin width (B)}

It is the width of the watershed and was determined by using the following equation;
$\mathrm{B}=\frac{\mathrm{A}}{\mathrm{L}_{\mathrm{b}}}$

Where,

$\mathrm{A}=$ Area of the basin, $\mathrm{km}^{2}$

$\mathrm{L}_{\mathrm{b}}=$ Basin length, $\mathrm{km}$

\section{Bifurcation ratio $\left(\mathbf{R}_{\mathbf{b}}\right)$}

It is related to the branching pattern of the drainage network. It was determined by using the following equation;

$\mathrm{R}_{\mathrm{b}}=\frac{\mathrm{N}_{\mathrm{u}}}{\mathrm{N}_{\mathrm{u}+1}}$

Where,

$N_{u}=$ Number of streams of the given order

$\mathrm{N}_{\mathrm{u}+1}=$ Number of streams of the next higher order

Mean stream length $\left(\overline{\mathrm{L}}_{\mathrm{u}}\right)$

Length of stream is indicative of the contributing area of the basin of that order. The stream length is used to determine the basin perimeter, basin length and drainage density.

It was calculated by using the following equation;

$\bar{L}_{u}=\frac{\sum_{i=1}^{N} L_{u}}{N_{u}}$

Where,

$\mathrm{N}_{\mathrm{u}}=$ Number of streams of the given order

$\mathrm{L}_{\mathrm{u}}=$ Length of stream having order $\mathrm{u}, \mathrm{m}$ 


\section{Stream length ratio $\left(\mathbf{R}_{\mathrm{L}}\right)$}

Lengths of each stream segment of each order were measured for the watershed. The total and mean lengths and the length ratios were calculated for the watershed using the following expression;

$\mathrm{R}_{\mathrm{L}}=\frac{\overline{\mathrm{L}_{\mathrm{u}}}}{\overline{\mathrm{L}_{\mathrm{u}-1}}}$

Where,

$\mathrm{L}_{\mathrm{u}}=$ The total stream length of the order ' $\mathrm{u}$ '

$\mathrm{L}_{\mathrm{u}-1}=$ The total stream length of its next lower order.

\section{Areal aspects of drainage area}

The aerial aspects play a very important role in the watershed development and these are very essential characteristics of the watershed.

The aerial parameters such as drainage area, drainage density, stream frequency, form factor, circulatory ratio, circulatory index, elongation ratio, compactness co-efficient, ellipticity index and texture ratio were determined using drainage map in QGIS environment. The detailed calculation of these parameters is explained hereunder.

\section{Drainage density $\left(\mathbf{D}_{\mathrm{d}}\right)$}

Drainage density is derived as the ratio of total stream segment length cumulated for all orders to the drainage area (A) and calculated using the following equation;

$\mathrm{D}_{\mathrm{d}}=\frac{\sum_{\mathrm{i}=1}^{\mathrm{u}} \mathrm{L}_{\mathrm{u}} \times \mathrm{N}_{\mathrm{u}}}{\mathrm{A}}$

Where,
$\mathrm{D}_{\mathrm{d}}=$ Drainage density, $\mathrm{km} . \mathrm{km}^{-2}$

$\mathrm{L}_{\mathrm{u}}=$ Length of stream order, $\mathrm{km}$

$\mathrm{N}_{\mathrm{u}}=$ Number of streams

$\mathrm{A}=$ Area of watershed, $\mathrm{km}^{2}$

\section{Stream frequency $(\mathbf{F})$}

It is defined as number of stream segments per unit area and was calculated by using the following equation;

$\mathrm{F}=\sum_{\mathrm{i}=1}^{\mathrm{u}} \frac{\mathrm{N}_{\mathrm{u}}}{\mathrm{A}}$

Where,

$\mathrm{Nu}=$ Total number of streams of all orders

$\mathrm{A}=$ Area of the basin, $\mathrm{km}^{2}$

\section{Form factor $\left(\mathbf{R}_{\mathbf{f}}\right)$}

It was measured as the dimensionless ratio of drainage area (A) to square of the length by using the following expression;

$\mathrm{R}_{\mathrm{f}}=\frac{\mathrm{A}}{\mathrm{L}_{\mathrm{b}}^{2}}$

Where,

$\mathrm{A}=$ Area of watershed, $\mathrm{km}^{2}$

$\mathrm{L}=$ length of the basin, $\mathrm{km}$

\section{Circulatory ratio $\left(\mathbf{C}_{\mathbf{r}}\right)$}

It was measured as dimensionless ratio of basin area (A) to the area of a circle $\left(\mathrm{A}_{\mathrm{c}}\right)$ whose circumference is the same as that of the basin perimeter $\left(\mathrm{P}_{\mathrm{b}}\right)$ by using the following expression;

$$
C_{r}=\frac{4 \Pi}{\mathrm{P}_{\mathrm{b}}^{2}}
$$


Where,

$\mathrm{P}=$ Perimeter, $\mathrm{km}$

The value of circulatory ratio varies from zero (in a line) to one (in a circle).

Higher the values of circulatory ratio, more circular will be the shape of the basin and vice-versa.

\section{Elongation ratio $\left(\mathbf{E}_{\mathbf{r}}\right)$}

Elongation ratio is the ratio of the diameter of a circle which has same area as the basin to the maximum length of the basin, which was calculated by using the following equation;

$\mathrm{E}_{\mathrm{r}}=\frac{2 \mathrm{R}_{\mathrm{e}}^{\prime}}{\mathrm{L}_{\mathrm{b}}}$

Where,

$R_{e}=$ Radius of circle equivalent to area of the watershed, $\mathrm{km}$

$\mathrm{L}_{\mathrm{b}}=$ Length of the basin, $\mathrm{km}$

$R_{e}$ is given by $A=\pi\left(R_{e}\right)^{2}$ and $A$ is area of watershed

\section{Compactness coefficient $\left(\mathbf{C}_{\mathfrak{c}}\right)$}

It was measured as the ratio of the perimeter of watershed $\left(\mathrm{P}_{\mathrm{b}}\right)$ to the circumference $\left(\mathrm{P}^{\prime}{ }_{\mathrm{b}}\right)$ of a circle equivalent to the area of the watershed, which is expressed below,

$$
\mathrm{C}_{\mathrm{c}}=\frac{\mathrm{P}_{\mathrm{b}}}{\mathrm{P}_{\mathrm{b}}^{\prime}}
$$

Where,

$\mathrm{A}=$ Area of watershed, $\mathrm{km}^{2}$

$\mathrm{P}_{\mathrm{b}}=$ Perimeter of the basin, $\mathrm{km}$

\section{Ellipticity index $\left(\mathbf{E}_{\mathbf{i}}\right)$}

The value of ellipticity index varies from 1.0 to infinity and it is inversely proportional to the form factor. Ellipticity index was calculated using the following formula;

$\mathrm{E}_{\mathrm{i}}=\frac{\pi \mathrm{L}^{2}}{4 \mathrm{~A}}$

Where,

$\mathrm{A}=$ Area of watershed, $\mathrm{km}^{2}$

$\mathrm{L}=$ Length of watershed, $\mathrm{km}$

\section{Texture ratio $\left(\mathbf{R}_{\mathbf{t}}\right)$}

It is the number of first order streams per unit perimeter of length of the drainage basin.

It was calculated by using the following formula;

$\mathrm{R}_{\mathrm{t}}=\frac{\mathrm{N}_{1}}{\mathrm{P}}$

Where,

$\mathrm{N}_{1}=$ Number of first order streams

$\mathrm{P}=$ Basin perimeter, $\mathrm{km}$

\section{Relief aspects of stream network}

The relief aspects are important terrain parameters from utilization point of view and also in assessing disaster prone areas.

The slope is very important for assessing land capability, erodibility and stability. In order to derive the relief aspects, the contours developed from DEM for the Patapur watershed were used.

The detailed calculation of relief aspects of stream network is explained hereunder. 


\section{Stream slope (S)}

The stream slope has profound effect on the velocity of flow and in turn on the discharge from the drainage area.

The slope of the drainage area was computed as the fall from the head of the first order channel to the gauging station divided by the main stream length $\left(\mathrm{L}_{\mathrm{c}}\right)$.

\section{Maximum watershed relief $(\mathbf{H})$}

Maximum watershed relief $(\mathrm{H})$ is the elevation difference between basin mouth (discharge point) and the highest point on the basin perimeter. Maximum watershed relief for the present study was determined from the contour lines.

\section{Relative relief $\left(\mathbf{R}_{\mathbf{R}}\right)$}

It is the product of maximum watershed relief to the length of perimeter. It was computed by using the following formula;

$$
\mathrm{R}_{\mathrm{R}}=\frac{\mathrm{H}}{\mathrm{L}_{\mathrm{p}}}
$$

Where,

$\mathrm{R}_{\mathrm{R}}=$ Relative relief, \%

$\mathrm{H}=$ Maximum watershed relief, $\mathrm{m}$

$\mathrm{L}_{\mathrm{p}}=$ Length of perimeter, $\mathrm{m}$

\section{Relief ratio $\left(\mathbf{R}_{\mathbf{r}}\right)$}

It is ratio of maximum watershed relief divided by the maximum watershed length. It was computed by using following expression;

$$
\mathrm{R}_{\mathrm{r}}=\frac{\mathrm{H}}{\mathrm{L}_{\mathrm{b}}}
$$

Where,
$\mathrm{R}_{\mathrm{r}}=$ Relief ratio

$\mathrm{L}_{\mathrm{b}}=$ Basin length, $\mathrm{km}$

$\mathrm{H}=$ Maximum watershed relief, $\mathrm{m}$

\section{Ruggedness number $\left(\mathbf{R}_{\mathbf{N}}\right)$}

The product of relief $(\mathrm{H})$ and drainage density $\left(D_{d}\right)$ is called as ruggedness number. It was calculated by the following expression;

$\mathrm{R}_{\mathrm{N}}=\mathrm{H} \times \mathrm{D}_{\mathrm{d}}$

Where,

$D_{\mathrm{d}}=$ Drainage density, $\mathrm{km} \cdot \mathrm{km}^{-2}$

$\mathrm{H}=$ Watershed relief, $\mathrm{m}$

\section{Geometric number}

The geometric number is a ratio of Ruggedness number to the slope of the ground surface. It was calculated by the following expression;

Geometric number $=\frac{\mathrm{HxD}_{\mathrm{d}}}{\mathrm{S}_{\mathrm{g}}}$

Where,

$\mathrm{S}_{\mathrm{g}}=$ Slope of ground surface, $\mathrm{km} \cdot \mathrm{km}^{-1}$

$\mathrm{H}=$ Maximum watershed relief, $\mathrm{m}$

\section{Time of concentration $\left(\mathbf{T}_{c}\right)$}

The time required for runoff water to move from the most remotest point of the watershed to its outlet is called as time of concentration $\left(\mathrm{T}_{\mathrm{c}}\right)$. It was obtained from the following expression;

$$
\mathrm{T}_{\mathrm{c}}=3.97 \mathrm{~L}^{0.77} \mathrm{~S}^{-0.385}(18)
$$

Where,

$\mathrm{T}_{\mathrm{c}}=$ Time of concentration, $\min$ 
$\mathrm{L}=$ Length of watershed from remotest point to outlet, $\mathrm{km}$

$\mathrm{S}=$ Slope of the catchment, $\mathrm{mm}^{-1}$

\section{Basin relief $(\mathbf{S})$}

The basin relief is measured as the ratio of elevation difference between highest elevation (HE) point in the basin and lowest elevation (LE) at gauging station divided by main valley length. It was calculated by using following equation;

Basin relief $=\frac{\mathrm{HE}-\mathrm{LE}}{\mathrm{L}} \times 100$

Where,

$\mathrm{L}=$ Length of basin, $\mathrm{m}$

$\mathrm{HE}=$ Highest elevation, $\mathrm{m}$

LE $=$ Lowest elevation, $m$

The terrain analysis tool of QGIS was used to derive the Digital Elevation Model (Fig. 2), slope map (Fig. 3) contour map (Fig. 4) and relief map (Fig. 5) from SRTM. The derived slope map for the micro watershed was reclassified using re-class tool of QGIS to slope ranging between 1 to 68.5 per cent.

\section{Results and Discussion}

The geomorphological analysis and measurements were made from the digitized drainage pattern map of the Patapur microwatershed. Watershed boundary and digitized drainage pattern are shown in Figure 6.

\section{Linear aspects of drainage network}

The stream order, stream number, bifurcation ratio and stream length ratio were analyzed for the micro-watershed. The micro-watershed comprises an area of 488.75 ha with a perimeter of $10950.12 \mathrm{~m}$ and basin length of $3855.25 \mathrm{~m}$. The micro-watershed has total 12 streams with highest stream of $3^{\text {rd }}$ order and drainage pattern resembles to dendrite. The length of $1^{\text {st }}$ order, $2^{\text {nd }}$ order and $3^{\text {rd }}$ order were 3853.2, 2908.7and 488.10 respectively. It observed from the Table 1 that, mean stream length varied from 488.10 to $727.17 \mathrm{~m}$.

However, in general, the mean length of the stream of the particular order increases with the increase in the order of stream which means the mean length of a stream of a given order is greater than that of immediate lower order. But, in the present case, mean stream length of the third order is lesser than its immediate lower order which might be due to variations in slope and topography. The other important property i.e. bifurcation ratio $\left(\mathrm{R}_{\mathrm{b}}\right)$, it is observed from the Table 1 , the $R_{b}$ is not same from one order to its next order and it varied from 1.75 to 4.00 with average $R_{b}$ of 2.88 .

The stream length ratio of the microwatershed ranged between 0.75 and 0.17 . The ratio depicts that lower reaches of the watershed had smaller channels (order 3 ) than the upper reaches (order 1 and 2). This may be because of the steeper slope in the upper reaches than in lower reaches.

\section{Relation between stream number and stream order}

The relationship between stream order and logarithm of stream number was plotted and is shown in the Figure 7. The graph clearly depicts there is one to one straight line relationship between the stream number and stream order which is satisfying the Horton's law of stream order. It is evident that the correlation coefficient and coefficient of determination for the straight line fit for the watershed were 0.97 and 0.94 , respectively which are quite satisfactory. 
Table.1 Morphological characteristics of study area

\begin{tabular}{|c|c|c|}
\hline Sl. No. & Morphological characteristics & Estimated values \\
\hline \multicolumn{3}{|c|}{ Linear Aspects Parameters } \\
\hline 1 & Area, ha & 488.80 \\
\hline 2 & Perimeter, $\mathrm{m}$ & 10950.12 \\
\hline 3 & Basin length $\left(\mathrm{L}_{\mathrm{b}}\right), \mathrm{m}$ & 3855.250 \\
\hline \multirow[t]{4}{*}{4} & Stream order & \\
\hline & I & 7 \\
\hline & II & 4 \\
\hline & III & 1 \\
\hline \multirow[t]{4}{*}{5} & Stream length $\left(\mathrm{L}_{\mathrm{u}}\right), \mathrm{m}$ & \\
\hline & 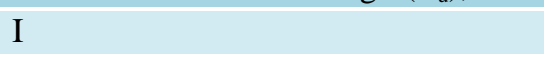 & 3853.20 \\
\hline & II & 2908.70 \\
\hline & III & 488.10 \\
\hline \multirow[t]{4}{*}{6} & Mean stream length, $\mathrm{m}$ & \\
\hline & 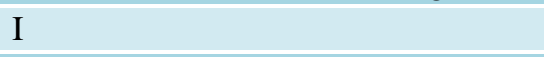 & 550.00 \\
\hline & II & 727.17 \\
\hline & III & 488.10 \\
\hline \multirow[t]{4}{*}{7} & Bifurcation ratio $\left(\mathrm{R}_{\mathrm{b}}\right)$ & \\
\hline & 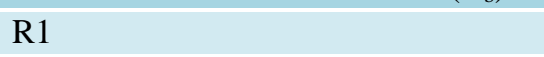 & 1.75 \\
\hline & $\mathrm{R} 2$ & 4.00 \\
\hline & Mean & 2.88 \\
\hline \multicolumn{3}{|c|}{ The areal aspects parameters } \\
\hline \multirow[t]{4}{*}{8} & Stream length ratio $\left(\mathrm{L}_{\mathrm{u}}\right)$ & \\
\hline & 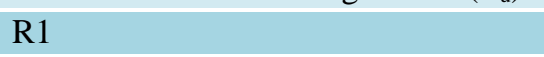 & 0.75 \\
\hline & $\mathrm{R} 2$ & 0.17 \\
\hline & Mean & 0.46 \\
\hline 9 & Drainage density $\left(D_{d}\right), \mathrm{km} \mathrm{km}^{-2}$ & 1.48 \\
\hline 10 & Stream frequency $(\mathrm{F})$, no.ha $^{-1}$ & 0.025 \\
\hline 11 & Drainage Texture $\left(D_{t}\right)$, no.km $^{-1}$ & 1.096 \\
\hline 12 & Farm factor $\left(\mathrm{R}_{\mathrm{f}}\right)$ & 0.329 \\
\hline 13 & Circularity ratio $\left(\mathrm{R}_{\mathrm{c}}\right)$ & 0.512 \\
\hline 14 & Elongation ratio $\left(\mathrm{R}_{\mathrm{e}}\right)$ & 0.647 \\
\hline 15 & Length of overland flow $\left(\mathrm{L}_{\mathrm{g}}\right), \mathrm{km} \mathrm{km}^{2}$ & 1.350 \\
\hline 16 & Compactness coefficient $\left(\mathrm{C}_{\mathrm{c}}\right)$ & 1.398 \\
\hline 17 & Circulatory index $\left(\mathrm{I}_{\mathrm{c}}\right)$ & 0.512 \\
\hline 18 & Avg. basin width, m & 1267.88 \\
\hline 19 & Shape factor $\left(S_{b}\right)$ & 2.28 \\
\hline \multicolumn{3}{|c|}{ The relief aspects parameters } \\
\hline 20 & Texture ratio $\left(\mathrm{R}_{\mathrm{t}}\right)$ & 0.639 \\
\hline 21 & Ruggedness no. $\left(\mathrm{R}_{\mathrm{N}}\right)$ & 0.744 \\
\hline 22 & Geometric No. & 0.0029 \\
\hline 23 & Relief ratio $\left(\mathrm{R}_{\mathrm{r}}\right), \mathrm{km}^{2}$ & 0.130 \\
\hline 24 & Relative relief $\left(\mathrm{R}_{\mathrm{R}}\right)$ & 0.050 \\
\hline 25 & Total relief $(\mathrm{H})$ & 114.00 \\
\hline 26 & Constant of channel maintenance (C) & 0.46 \\
\hline 27 & Time of concentration $\left(T_{c}\right)$ & 36.64 \\
\hline
\end{tabular}


Fig.1 Location map of Patapur microwatershed in the Raichur district of Karanataka

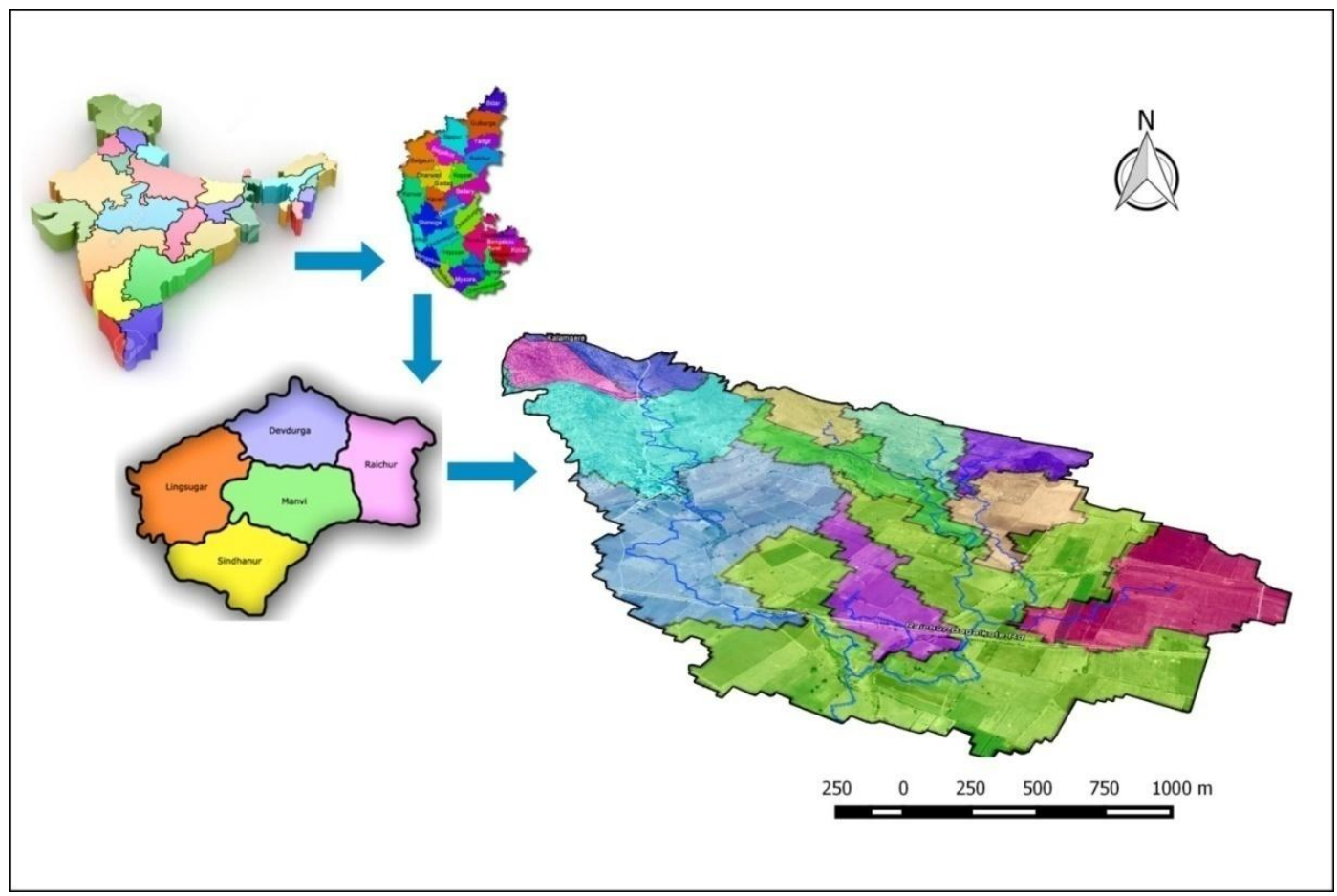

Fig.2 DEM map of Patapur micro-watershed

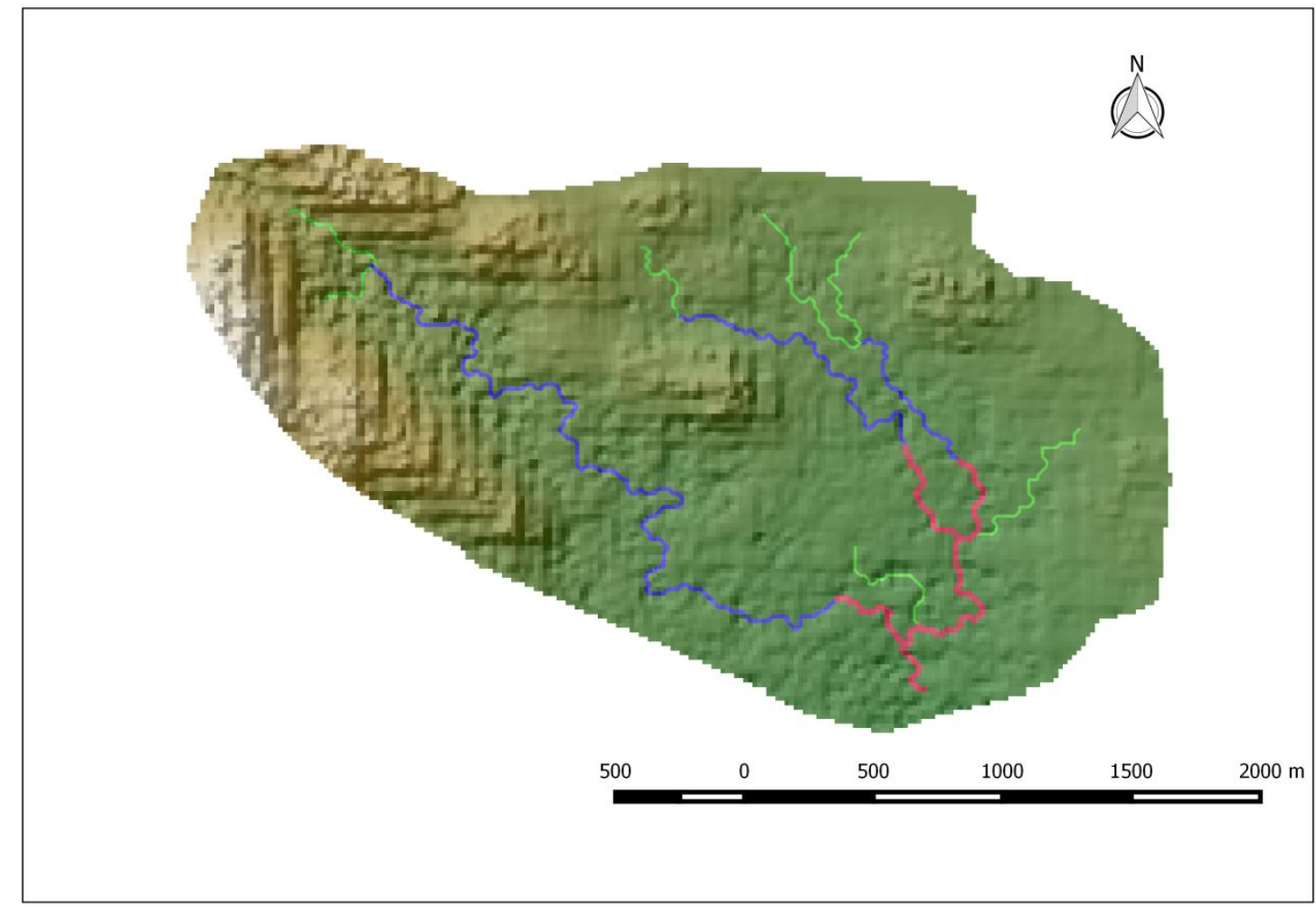


Fig.3 Slope map of Patapur micro-watershed

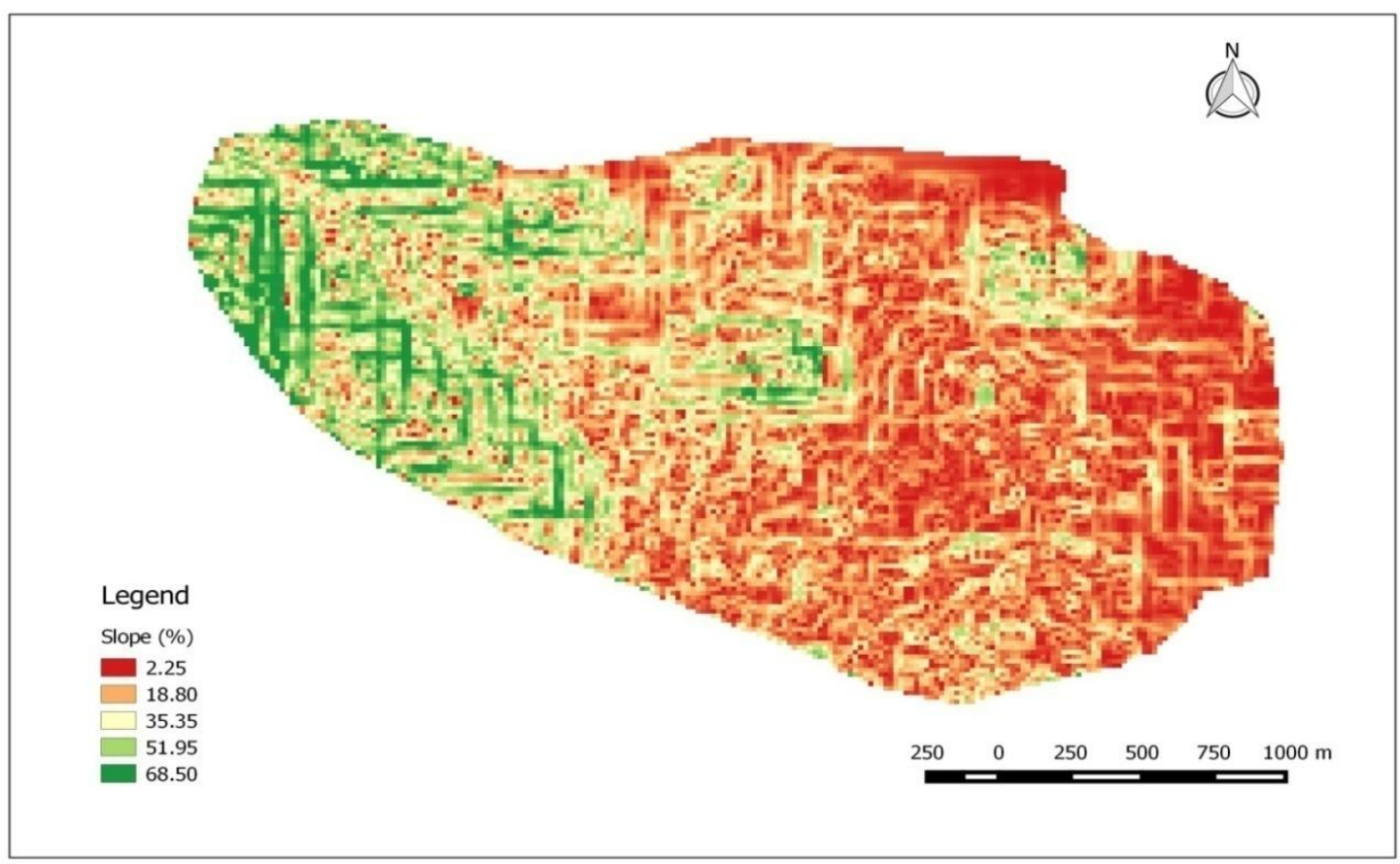

Fig.4 Contour map of Patapur micro-watershed

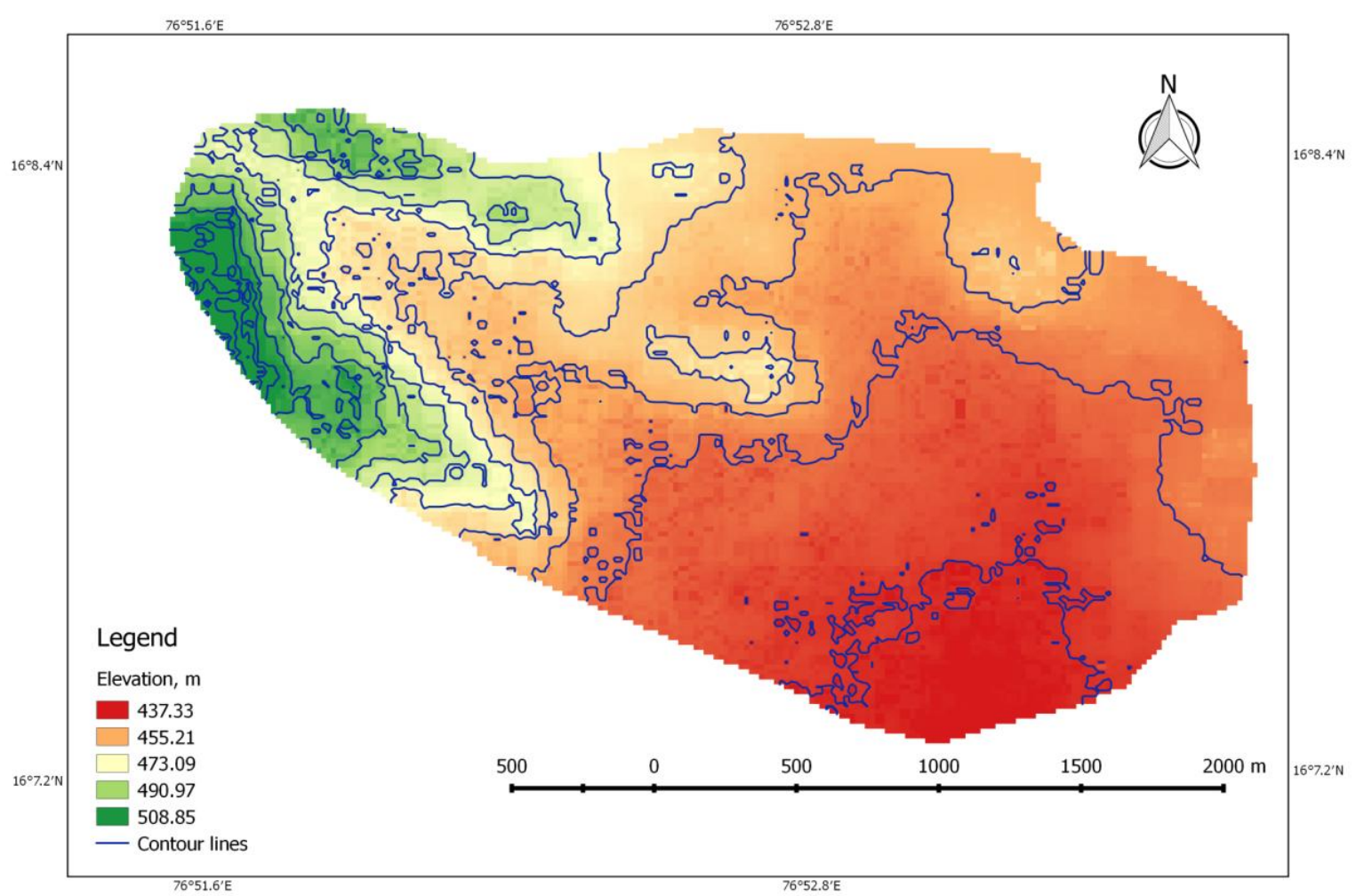


Fig.5 Relief map of Patapur micro-watershed

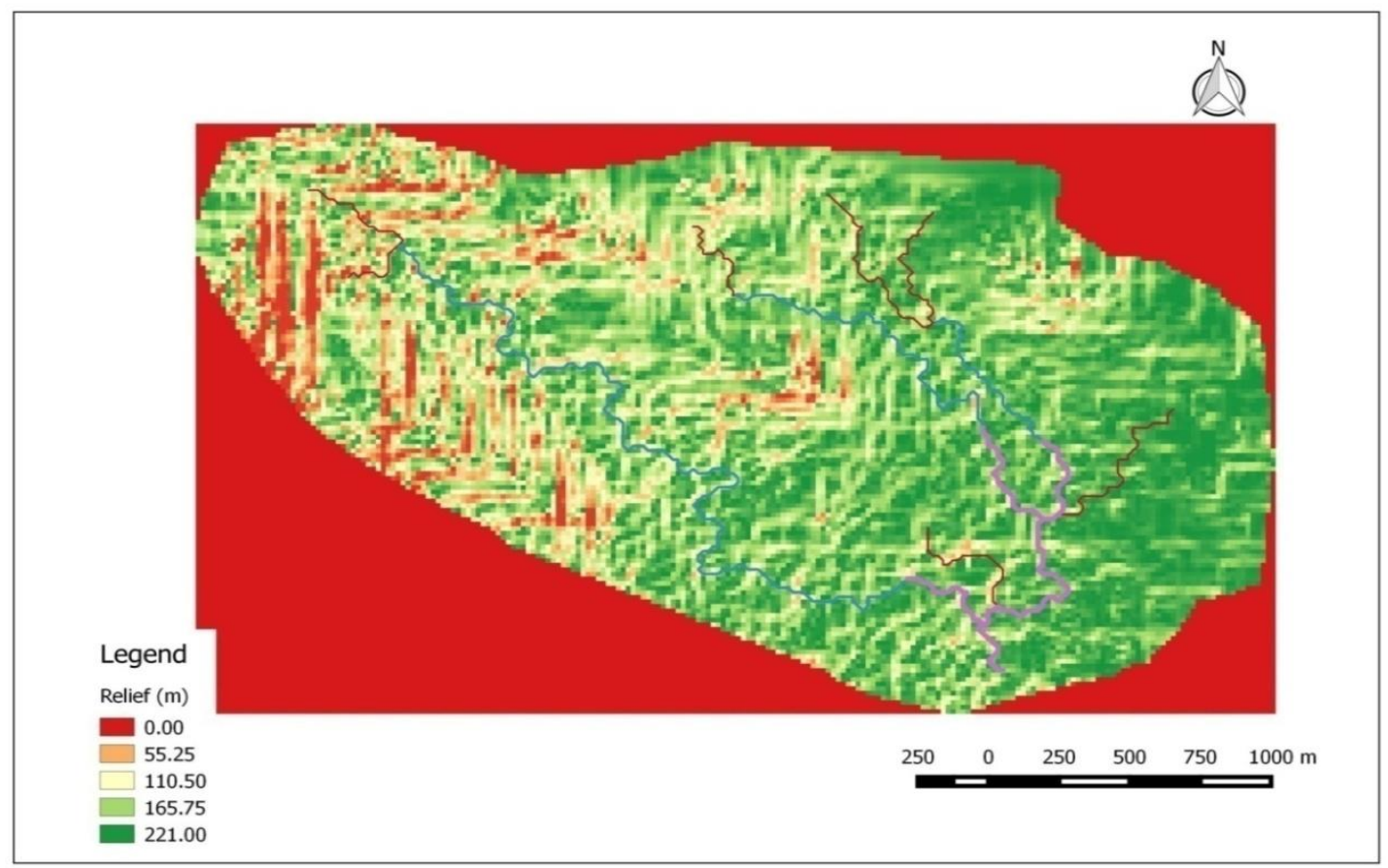

Fig.6 Stream network map with delineation of contributing area of each stream in Patapur micro-watershed

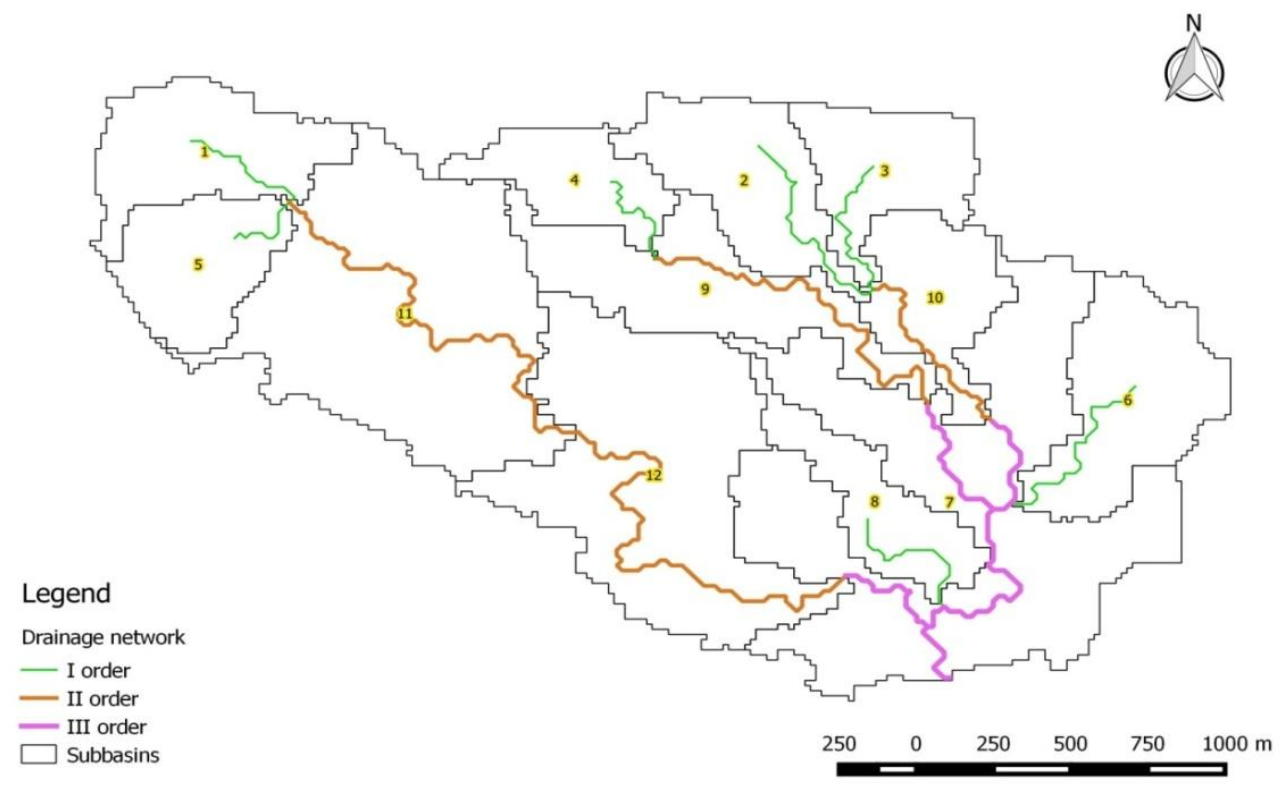


Fig.7 Regression of logarithm of number of streams and stream order

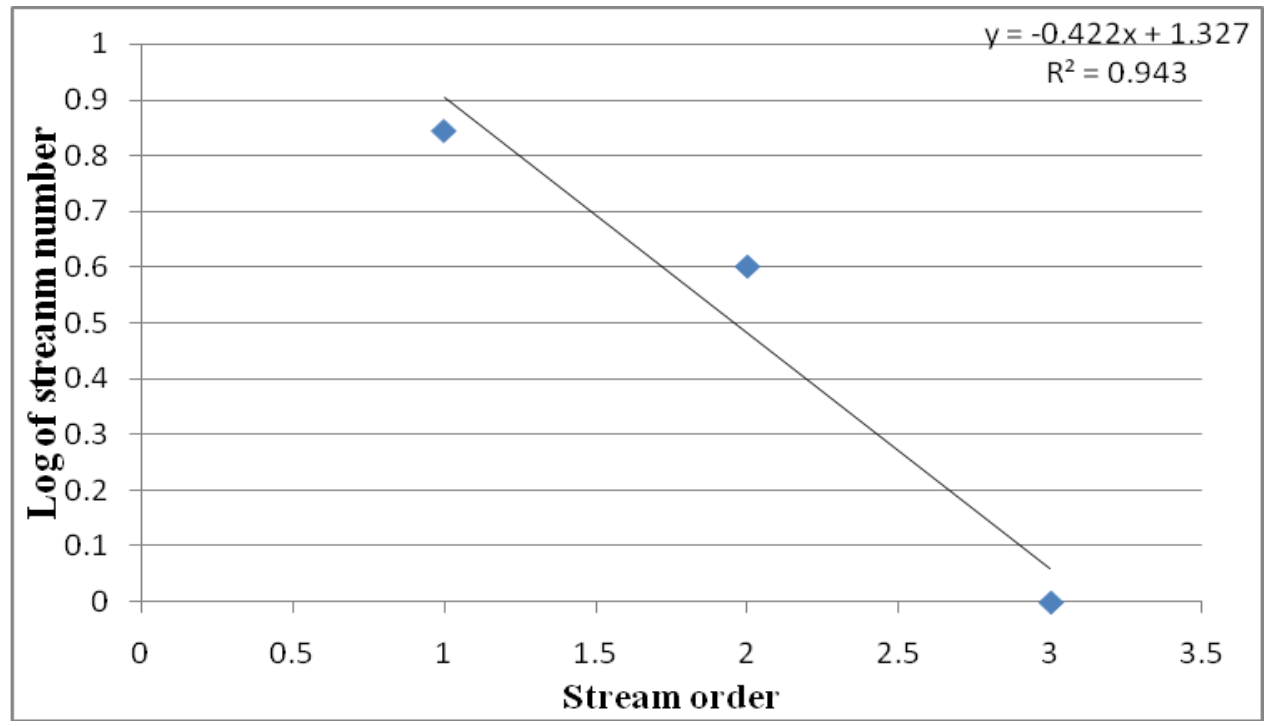

Fig.8 Regression of logarithm of cumulative stream length and stream order

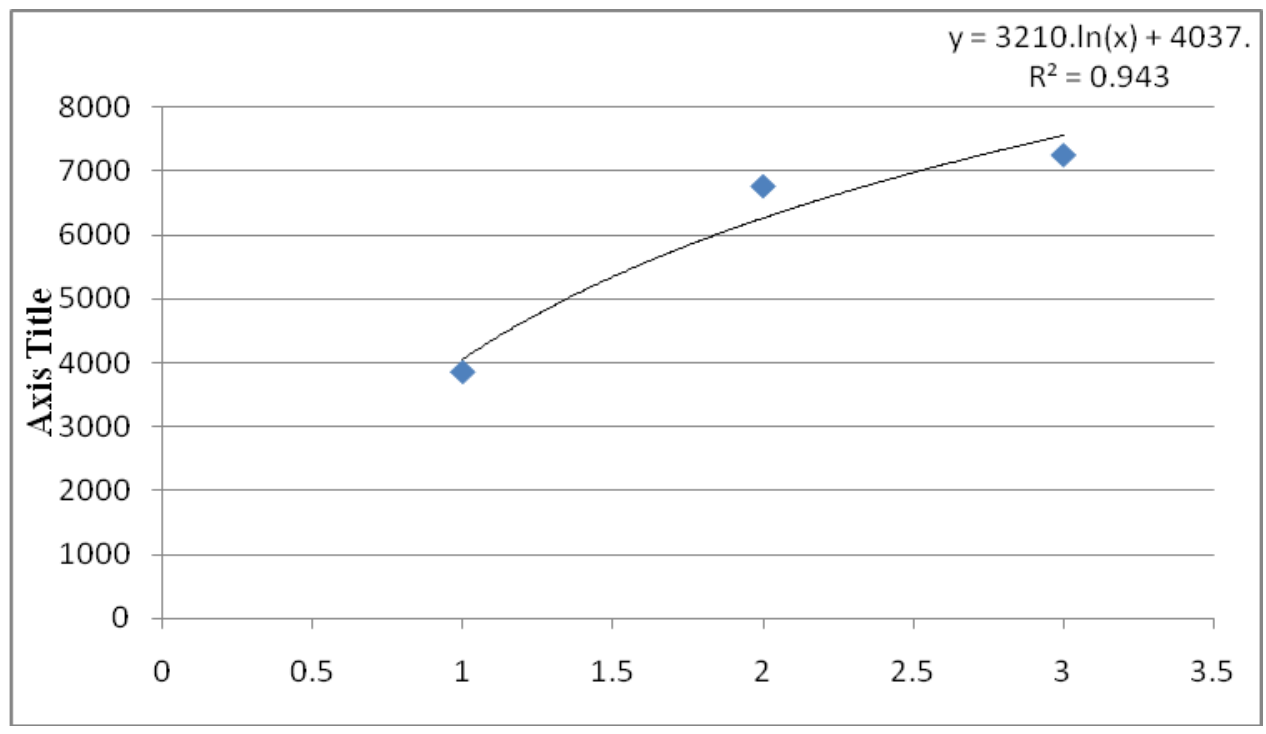

Relation between cumulative stream length and stream order

The plot of logarithm of cumulative stream length vs stream order is straight line fit which is shown in the Figure 8. The straight line fit denotes that the ratio between cumulative stream lengths is constant throughout the successive order of a basin and suggests that geometrical similarity is preserved in basins of increasing order. It is clearly evident that the correlation co-efficient and coefficient of determination for the straight line fit for the watershed were 0.80 and 0.64 , respectively.

\section{Areal aspects of watershed}

Form factor, circulatory ratio and elongation ratio can be used for evaluation of stream flow characteristics of a drainage basin. Form factor is a good indicator of outline form of a drainage basin, the value of which is 0.329 . This low 
form factor value indicates that the watershed has moderately high low peak flows for shorter duration. The circulatory ratio is computed as 0.512 and the elongation ratio as calculated is 0.647 (Table 1).

These values indicate elongated with high relief and steep slope which may give rise elongated peak flow. Srinivasa et al., (2004) was also reported the similar results for Pavagad area of Tumkur District with form factor varied from 0.19 to 0.85 indicated that one watershed out of nine were circular and remaining were elongated in shape followed by Sahebgouda et al., (2016) also found the lower value of form factor of 0.32 for Devasugur nala watershed in the Raichur district of Karnataka state and also, the results are in agreement with close findings of Kuldeep et al., (2011). The texture ratio of the watershed was 0.639 and categorized as low in slope and flat watershed. Similar results were observed in the works of Kuldeep et al., (2011).

\section{Relief aspects of channel network}

The relative relief of Patapur micro watershed is 0.05. This is an indication of areas with moderate to high relief. In the present study, relief ratio was found to be 0.130 (Table 1). The $\mathrm{R}_{\mathrm{h}}$ normally increases with decreasing drainage area and size of a given drainage basin (Shakil et al., 2012).

It is the length of water over the ground before it gets concentrated into definite stream channels. This factor relates inversely to the average slope of the channel and is quite synonymous with the length of sheet flow to a large degree. The $\mathrm{L}_{\mathrm{g}}$ value of the study area is 1.350 (Table 1) which indicates high relief of watershed. This is an indication of possibly moderate erosion and reflects that the watershed be treated with soil and water conservation measures.

Strahler (1964) expressed that ruggedness number is the product of the basin relief and the drainage density and usefully combines slope steepness with its length. Calculated accordingly, the Patapur micro-watershed has a ruggedness number of 0.744 . The higher ruggedness value of watershed implied that area is more prone to soil erosion and have intrinsic structural complexity in association with relief and drainage density. These results are in agreement with the earlier findings of by Srinivasa et al., (2004).

Time of concentration directly influences on runoff generation from the watershed. For the present watershed the time of concentration was $36.64 \mathrm{~min}$ and it clearly indicated that generation of peak will be at earlier stage. The low value of time of concentration was found due to higher stream slope in the upper reach and shorter basin length.

Slope map (Fig. 2) provides information regarding the distribution of various slope classes that helps in understanding the runoff characteristics and drainage pattern of the area. In the micro-watershed area the North-West comprised strong sloping lands and towards East it was very gentle sloping. It is observed that slope class 5-10 per cent occupies 35.30 per cent, followed by $>25$ per cent $(20.33 \%), 2-5$ (19.65\%), 10-15 (16.32\%), 15-25 (6.69\%) and $0-2(1.72 \%)$ of the total watershed area. In the flat land watersheds of Raichur district, the slope class more than 25 per cent is occupied second highest $(20.33 \%)$ in the Patapur microwatershed, the reason is presence of local isolated hillocks and mounts in the watershed.

In the Patapur micro-watershed the stream length ratio varied from 0.75 to 0.17 , it reveals that, there is an increasing trend in the length ratio from lower order to higher order indicating their mature geomorphic stage. The bifurcation ratio $\left(R_{b}\right)$, varied from 1.75 to 4.00 with average $\mathrm{R}_{\mathrm{b}}$ of 2.88 which shows that an undistorted geologic structure and existence of drainage systems of moderate peaks and lower order streams were approximately 3.75 times more than subsequent higher order. It is also observed that the form factor $\left(R_{f}\right)$, shape factor $\left(S_{b}\right)$, circulatory ratio $\left(\mathrm{R}_{\mathrm{c}}\right)$ and elongation ratio $\left(\mathrm{R}_{\mathrm{e}}\right)$ were $0.329,2.28,0.512$ and 0.647 , respectively. The low value of $R_{f}(0.329)$ indicated that the 
watershed is moderately elongated shape. The low $\operatorname{Re}$ value $(0.647)$ indicates high relief and steep slope. The calculated value of over land flow $\left(\mathrm{L}_{\mathrm{g}}\right)$, compactness coefficient $(\mathrm{Cc})$ and shape factor $\left(\mathrm{S}_{\mathrm{b}}\right)$ for the micro-watershed were $1.350 \mathrm{~km} \mathrm{~km}^{-2}, 1.398$ and 2.28 respectively. The Estimated value of relief $(\mathrm{H})$ was $114 \mathrm{~m}$, based on which relief ratio $\left(\mathrm{R}_{\mathrm{r}}\right)$ and relative relief $\left(R_{R}\right)$ were found to be 0.130 and $0.05 \mathrm{~km}$ respectively, these indicates the possibly moderate erosion and reflects that the watershed is to be treated with soil and water conservation measures. The Ruggedness number $\left(\mathrm{R}_{\mathrm{N}}\right)$ and geometric number were computed and values were 0.744 and 0.0029 , respectively. With high value of Ruggedness number (0.744) is evident that watershed is having high slope in some parts of the watershed.

\section{References}

Horton, R. E., 1945, Erosional development of streams and their drainage basins, hydrophysical approach to quantitative morphology. Geol. Soc. America, 56: 275-370.

Kuldeep, P. and Upasana, P., 2011, Quantitative morphometric analysis of a watershed of Yamuna basin, India using aster (DEM) data and GIS. Int. J. Geomatics and Geosci., 2(1): 248-269.

Sahebagouda, N. P., Maheshwar Babu, B., Srinivasa Reddy, G. V., Polisgowdar, B. S., and Shanwad, U. K., 2016, Charectrisation of geo-morphological features of Devasugur nala watershed at Krishna basin of Karnataka using Geographical Information Systems (GIS). Indian J. Soil Conser., 44(2): 185-190.

\section{How to cite this article:}

Premanand, B.D., U. Satishkumar, B. Maheshwara Babu, S.K. Parasappa, Mallikarjuna M. Dandu, Ibrahim Kaleel, N.L. Rajesh and Biradar, S.A. 2018. Morphometric Analysis of Patapur Microwatershed in North-Eastern Dry Zone of Karnataka Using Geographical Information System: A Case Study. Int.J.Curr.Microbiol.App.Sci. 7(04): 853-866.

doi: https://doi.org/10.20546/ijcmas.2018.704.093
Sethupathi, A. S., Lakshmi, N. C., Vasanthamohan, V. and Mohan, S. P., 2011, Prioritization of mini-watersheds based on morphometric analysis using RS and GIS techniques in a draught prone Bargur Mathur sub-watersheds, Ponnaiyar river basin. Int. J. Geomatics and Geosci., 2(2): 403-414.

Shakil, A. R., Shakeel, A. B. and Irfan, R., 2012, Georeferencing for assessing the morphometric controlling of hydrological response at watershed scale in the upper Indus basin. J. Earth System Sci., 121(3): 4499-4509.

Srinivasa Raju, K. and Nagesh Kumar, D., 2011, Classification of Microwatersheds based on morphological characteristics. Int. Asso of Hydro-environment Engg. and Res., 5: 101-109.

Srinivasa Vittala, S., Govindaiah, S., and Honne Gowda, H., 2004, Morphometric analysis of sub-watersheds in the Pavagada area of Tumkur district, south India using remote sensing and GIS techniques. $J$. of the Indian Soc. of Remote Sens., 32(4): 351362.

Strahler, A. N., 1964, Quantitative geomorphology of drainage basin and channel network, Handbook of applied hydrology, McGraw Hill, New York, pp. 39-76.

Vinoth, M., Suresh, M. and Gurugnanam, B., 2014, Characteristics of drainage morphological studies using GIS in Kolli hills, central of Tamil Nadu, India. Int. J. Remote Sens. Geo. Sci., 3(3): 10-15. 